\title{
Using the 'New Age Atlantis' Case Study for Global Education Components of Geography Lessons Across Lower Secondary Schools in Czechia *
}

\section{Petra KARVÁNKOVÁ1}

University of South Bohemia, České Budějovice, CZECHIA

\section{Dagmar POPJAKOVÁ2}

Matej Bel University, Banská Bystrica, SLOVAKIA

\section{Tatiana MINTÁLOVÁ}

\section{Matej Bel University, Banská Bystrica, SLOVAKIA}

*A portion of this paper was presented in 2. International Congress on Geographical Education (UCEK/ICGE-2019), 3-5 October 2019, Eskişehir-Turkey.

'Assist. Prof.; University of South Bohemia, České Budějovice, Czechia, e-mail, ORCID: 0000-0002-5513-2161

2 Corresponding author: Assoc. Prof.; Matej Bel University, Department of Geography and Geology, Banská Bystrica, Slovakia. dagmar.popjakova [at] umb.sk. ORCID: 0000-0002-0724-6287

${ }_{3}^{3}$ Assist. Prof.; Matej Bel University, Department of Geography and Geology, Slovakia. ORCID: 0000-000 1-6806-4412

\section{Abstract}

A case study entitled 'New Age Atlantis or Mysterious Seventh Continent' was developed as an exemplar model to show how the teaching methods and themes of Global Education (GE) can be used in geography lessons. The main intent of this article is to share an example of good practice about the use of this case study in geography lessons in Czechia. The aim of the study was twofold: to develop an understanding about how plastics contribute to ocean pollution, as a serious and current ecological topic in Global Education; as well as to show how the characteristics and movement of ocean water are related to the topic of ocean pollution. The main research goal was to study how pupils were able to put their skills and knowledge in practice by fulfilling the objective of the teaching activity - to understand global ocean pollution. The teaching activity is based on methods which develop principles of critical thinking, learning by living, brainstorming, discussion, and group teaching. The teaching activity also allows for cross-curricular links to occur between school geography and other subjects including biology, physics, civic education, ecological education, and personal and social education. The teaching activities for the 'New Age Atlantis' case study is aimed at pupils aged between 12 to 15 years. The case study results confirm that as pupils collaborate and communicate with their peers and teachers, they learn to critically accept the opinions of others and, at the same time, to defend their own opinions. All of the pupils were able to understand and recognize the problem at hand.

\section{Keywords}

Geography Teaching, Global Education, Cross-curricular Links, Plastic Ocean Pollution 


\section{Principles and Issues of Global Education}

Global Education (GE) approaches seek to develop a holistic approach towards understanding the world; namely, GE responds to the need to perceive the world as a complex, multilateral unit (Pike \& Selby 1988). The topics covered in GE will directly or indirectly affect all of humankind. Such topics present the principles of solidarity, participation, responsibility of individuals, openness and social justice. On one hand, there are socially-oriented topics which accompany human society, such as inequality, liability, deficiency, discrimination, conflicts, etc.; and are the result of a different pace and conditions of development amongst communities and individuals. On the other hand, there are environmentally focused issues that correspond with a shortsighted perspective and approach of people and communities towards the potential of the environment they live in.

Altogether, the questions and issues raised in GE broadly touch on the quality and dignity of human lives; humanity as a whole and every individual. The goal of GE is to promote empathy and to search for objective and subjective solutions to the investigated tensions. The keystone of GE is to lead humankind and individuals, with an emphasis on the youngest generations, towards an emphatic approach towards the development of perception, recognition and understanding about a wide-range of social and environmental issues from the local to regional to global scales.

GE thematically involves developmental education, intercultural and multicultural education, education towards human rights, sustainable development, and peace and conflict prevention. These topics are part of the global dimension of education towards citizenship (O'Loughlin \& Wegimont, 2008, p. 8; Cabezudo et al., 2008). The main intention of GE is to understand the link between our place in the current world and the role we have in it (Belgeonne \& Crombie, 2013; Miléřová, 2015).

It is possible to follow the decades-long progress of methods, mainly with children, which search for ways to focus education towards the development of a societal understanding about global issues (e.g. Anderson, 1968). Although GE topics are traditionally related to education, they are currently being developed and extended to be more up-to-date than previously, and focus on the sharing the conditions, results and news of global conflicts. The concept of GE and its' topics form an imminent part of current activity by national and transnational educational organizations, and are also becoming part of national educational curricula.

\section{Global Education as a Tool for Forming Socially and Ecologically Emphatic Individuals}

The goal of the education system should be to prepare young people to recognize their role and responsibility as a member of the global community, and to understand their lives in a global context (Department for Education, 2005). According to Pike (1997), Global Education (GE) is an approach to use with pupils who are aspiring to not only utilize their acquired knowledge, but also to acquire the mechanisms of effective use of this already acquired knowledge.

GE is not focused only on the perception of global contexts, but also on multilateral development of character. GE uses unorthodox methods and means 
to fulfil this goal, which are based on experience. Similar to other activating learning methods, GE activities should keep the principle of drawing close the relationship between pupils and teachers' relationship. Cabezudo et al. (2008, p. 38) metaphorically likens the relationship to:

A 'beehive where all the bees have one common goal and the only difference is that the teacher is not an authoritative king or queen'. The role of teacher is further compared to inductor in an orchestra where the 'conductor and every musician democratically decide on their program and their individual and collective role to achieve the final step of a harmonic symphony'.

The 'GE teacher' invites their pupils to individually explore contexts and to discover knowledge in a complex way. As a result, such teachers should be able to demonstrate ways of acquiring information and teach their pupils how to participate in public life. A 'GE teacher' will inspire their pupils through the use of enquiry-based approaches and foster the will to obtain knowledge. A 'GE teacher' is more of a guide than an authority. The basic requirement for a GE teacher, and a teacher of any educational form, is to know the level and possibilities of their pupils as individuals as well their pupils in the context of a whole class.

The need to consider the age, number of pupils in class, cultural and social differences in the context of the chosen topic, and finally the time requirements and environment is crucial when applying the GE topics into school education. The needs of individual pupils are the primary variable in this process (Pána \& Pospîsilová, 2012; Tarozzi \& Inguaggiato, 2018).

\section{Czech Practice of Global Education}

Global Education (GE) has been developing in Czech learning environments since the nineties. The initiatives from non-profit organizations, such as People in Need, have made GE opportunities possible since 1994 in Czechia. 'People in Need' develop GE activities within its framework variants (PINcz, 2019). In Czech learning environments, GE is labelled as 'Global Development Education', and it relates to the tradition of developing the capability of cooperation (Karvánková et al., 2017).

The Ministry of Foreign Affairs are a second channel of the development for GE in Czechia, and is also responsible for developing the capability of cooperation. The Ministry of Foreign Affairs oversees the Czech Development Agency (CDA) who developed the consequent educational program National Strategy for Global Development Education (GDE), and then expanded it at the behest of the Ministry (MZV ČR, 2011-15).

The Global Education (GE) material is based on an example from the British curriculum where the principles of Global Education are specified within eight points. The thematic framework of GE applied to the educational system in Czechia arose mainly out of four thematic spheres set in the National Strategy of GDE during the period of 2011-2015 (MZV ČR, 201 1-2015):

1. Globalization and mutual dependency of individual parts of the globe;

2. Human rights;

3. Global issues; and

4. Humanitarian assistance and development cooperation. 
The thematic spheres identified above were further specified and divided up into 22 topics overall (Karvánková et al., 2017).

\section{Multidisciplinary of Geography and Its Possibilities of Developing Global Issues}

Global Development Education (GDE) has not officially become part of the educational process so far, at any level in the Czech education system. Only Nádvorník \& Volfová (2004) have focused on the role of GDE in the Czech educational system at a high school level before the system was reformed in 2004. The social sciences (currently civics) and geography (and partly history) are mentioned as the most appropriate educational disciplines for applying the methodological principles of GDE (see Table 1). Nádvorník \& Volfová (2004) also point out the important role of cross-curricular subjects when applying GDE to the Czech educational system. Later, e.g. Dudková et al. (2012) identifies the potential of using the GE principles across a majority of school education subjects. Vaňková-Klímová \& Gajdíková (2013) suggest geography to be the most appropriate school subject for incorporating GE principles. The authoring team for this article put forward the idea that the topics related to the ecological and sustainable-development issues of natural landscapes are also very important in the educational field of Biology.

Table 1

Selected Educational Areas and Their Fields According to The Czech Framework Educational Programs (FEP BE CR) Practically Applying the Principles of Global Development Education (Belgeonne \& Crombie, 2013; MŠMT ČR, 2017, Edited by Authors)

\begin{tabular}{|c|c|c|}
\hline $\begin{array}{l}\text { Educational } \\
\text { areas } \\
\text { FEP BE CR }\end{array}$ & $\begin{array}{l}\text { Selected } \\
\text { educational } \\
\text { fields/educational } \\
\text { content }\end{array}$ & $\begin{array}{l}\text { Possibilities of fulfilling the principles of global } \\
\text { development education in the given } \\
\text { educational field }\end{array}$ \\
\hline \multirow[t]{2}{*}{ Man and society } & History & $\begin{array}{l}\text { Enables discovery about how global issues } \\
\text { have changed through the times. } \\
\text { Offers options to investigate the cause of } \\
\text { global poverty and conflicts }\end{array}$ \\
\hline & Civics & $\begin{array}{l}\text { Develops evaluation about diversity and } \\
\text { values to consider global challenges. } \\
\text { Deals with issues such as social justice, human } \\
\text { rights, community consistency and global } \\
\text { reciprocal dependence. } \\
\text { Discovering one's identity. }\end{array}$ \\
\hline \multirow{3}{*}{ Man and nature } & & $\begin{array}{l}\text { Searching for global reciprocal dependence } \\
\text { and global diversity. }\end{array}$ \\
\hline & Geography & $\begin{array}{l}\text { Critical access to global issues from many } \\
\text { points of view. } \\
\text { Inquiry for reciprocal dependence between } \\
\text { humanity and nature. } \\
\text { Can learn to differentiate and judge situations } \\
\text { from local, regional and global level } \\
\text { viewpoints. }\end{array}$ \\
\hline & Biology & $\begin{array}{l}\text { Description of changes in nature caused by } \\
\text { human activity and sheds light on their } \\
\text { consequences. } \\
\text { Observation of positive and negative } \\
\text { influence of people on the environment. }\end{array}$ \\
\hline
\end{tabular}


The thematic connection between the school subject of geography and GE is most prominent among related fields such as physics, chemistry, and biology. The multidisciplinary conception of geography develops both a scientific and a social disposition. Such dispositions enable pupils to obtain comprehensive insights and be able to understand nature and the surrounding world as a unitary functional system whose parts interact, affect each other, and have an effect on itself and the surroundings on different scales. Geography, including its aspects which pertain to the natural sciences is one of the main educational fields leading the way in conceptualizing education for global citizenship, and it has continually advanced in this way over recent years.

According to Miléřová (2015), such advancement comes from the development of many educational concepts in Western European countries over the last 40 to 50 years. Examples of these concepts include Development Education, Global Learning, Human Rights Education, and Education for Sustainable Development etc. (Hicks, 2003; Morgan, 2006; Bourn, 2008; Applis, 2014; Bullivant, 2014). Such concepts massively contribute to global citizenship education and are also closely connected to the educational field of Geography.

\section{Aim and Problems of the Case Study}

The case study entitled 'New Age Atlantis or Mysterious Seventh Continent' focuses on one of the basic issues included in Global Education (GE): environmental sustainability. The case study represents an example of learning activities for lower-secondary school pupils in Czechia. A detailed analysis of the case study is the focus for this article. The goal of the case study is to present possibilities about how teachers can work with pupils in their geography courses using GE themes and issues, for example, the issue of environmental pollution at a global scale. Specifically, the chosen issue is represented by investigating the way in which plastic products contribute to polluting the world's oceans.

The aim of the current study was to firstly tackle the serious current ecological topic about the role and contribution of plastics to the pollution of oceans; and secondly, to explain the features and movement of ocean water. The result of these two global processes is the creation of the "New Age Plastic Atlantis" case study. From an exploratory point of view, the main goal of this research about the use of the "New Age Plastic Atlantis" case study is to verify the extent to which pupils between 12-15 years of age are able to understand the issue of environmental pollution, and moreover, how much pupils understand about the issue at a global scale. The other goal of the research is to find out how relevant the issue of ocean pollution can be for those pupils who live inland.

The basic questions of the study can be summarized in the following:

- How were the pupils able to understand and recognize the problem?

- How were the pupils able to think about the problem at a global scale?

- Can a particular example of global ocean pollution enable pupils to understand the related natural processes?

- To what extent can the relatively abstract topic of pollution affect the pupils?

- Will the pupils be able to collaborate and communicate with their peers and teachers about the problem? 
- Will the pupils be able to stand-up for their opinions against scrutiny and accept the opinions of their peers?

The goal of the article is to analyze the use of the case study 'New Age Atlantis or Mysterious Seventh Continent' in great detail, taking into consideration a) methodological phases of activity; and b) the key supporting and inquisitive questions. The opening part of the current article analyses the significant approaches and principles of Global Education (GE), together with the implantation of GE in the Czechia education system, and the premise that teaching GE issues are evident in the school subject of geography.

\section{Methodology and Research Design}

As already stated in the introduction, the incorporation of global issues into school education have been developing in Czechia for almost 15 years. Such a situation is attributed to the activities of a non-profit organization "People in Need" (PINCz), and also in part due to the gestor activity of the Czech Ministry of Foreign Affairs. However, it has to be said that GE has not yet been welldeveloped into school curriculums. Nevertheless, due to the systematic work of non-profit organizations, a range of GE topics and methodologies are slowly yet systematically being introduced into initial teacher training programs (for Master's students) at universities.

During the academic year of 2014/15, in the Department of Geography and Faculty of Education at the University of South Bohemia in České Budějovice, global development education in geography was taught in the form of a seminar in response to a cooperative and common project with PINcz 'Teachers: Agents of Chance!'. Under the supervision of academic teachers, university students worked on practical schemes focused on GE topics which would be useful for implementation in Czech lower-secondary education.

Academic student conferences and workshops were then held on the university campus (Katedra geografie, 2019). More than 50 university students and almost 250 school children aged 12-15 years participated. The goal of the project was therefore realized in practice - namely, an intensified cooperation between the academic environment and school practice while expanding GE topics throughout the education system.

The case study "New Age Atlantis or Mysterious Seventh Continent", occurred during the 2016 spring. In a guidance role, the activities were facilitated by three Master's students and their academic advisor, who is one of the authors of this article. The academic advisor performed not only the role of the facilitator of the GE seminar but was also responsible for the data collection and procedure of analysis. Additionally, 25 pupils and their two teachers from two different schools, Česká Street Grammar School and Máj Lower-Secondary School in České Budějovice participated within the framework of the so-called 'Geography Inquiry Club' from the Department of Geography at South Bohemian University (Katedra geografie, 2019). Participation in these activities did not necessarily mean that the pupils came from an environment of where much interest in "research" or inquiry occurred, in fact, one of the schools is located a district with a higher percentage of socially-disadvantaged families. 
Karvánková, P., Popjaková, D. \& Mintálová, T. (2020). Using the 'New Age Atlantis' Case Study...

The case study uses modern teaching methods which develops the principles of critical thinking, learning by living, brainstorming, discussions, and group teaching in its individual phases. The realization of the study leans on qualitative methods of data collection (between the pupils and Master's students) and analysis procedures, such as observations, interviews, and question-forms prepared and applied by the Master's students. The methods of cross-case comparisons, analytical and natural generalizations were used during the collection and processing the information.

\section{Application of the Global Topic of Environmental Sustainability}

The case study, 'New Age Atlantis or Mysterious Seventh Continent' is designated for lower-secondary school pupils. It takes 65 minutes. Thematically, the activity corresponds with the educational subjects of geography, physics, biology and civics and the cross-curricular subjects - moral and social, and environmental education (Table 2).

The "New Age Atlantis or Mysterious Seventh Continent" consists of three main phases. The goal of the case study is for the pupils to know not only about what is happening to most of the plastics after they cease to be useful for people, but also about the physical laws that gradually create a continent of waste. Pupils can think critically about the following basic questions: What is their role during the creation of this continent? What can they personally do to make the situation better and is there even a way of improvement? The main goal of the activity is to stimulate pupil interest in the issue of ecology and recycling through the use of discussion, critical thinking and the posing of questions. It is important for pupils to realize how the world is connected with its environment; and also, for pupils to understand how they should behave and act in accordance with this knowledge in the future. (Kössl \& Chábera, 1999; Department for Education, 2005; TED Conferences, 2009; National Geographic, 2012; Algalita, 2016; MŠMT ČR, 2017).

\section{Table 2}

Linkup of the project of 'New Age Atlantis' to the Framework Educational Program for Basic Education in Czechia (MŠMT, 2017)

\begin{tabular}{|c|c|c|}
\hline $\begin{array}{l}\text { Educational } \\
\text { area }\end{array}$ & Subjects & Expected outcomes for pupils \\
\hline \multirow[t]{3}{*}{ Man and Nature } & Geography & $\begin{array}{l}\text { Pupils localize areas of plastics, 'islands' on map } \\
\text { Pupils know mandatory consequences and use chosen } \\
\text { examples to show the risks associated with the natural and } \\
\text { social impacts on the environment } \\
\text { Pupils realize the connectivity of the current world and how } \\
\text { the action of several countries can affect the conditions of } \\
\text { the whole world }\end{array}$ \\
\hline & Physics & $\begin{array}{l}\text { Pupils can explain the basic principles of thermodynamics } \\
\text { of sea currents and their effects on the position of trash } \\
\text { spots }\end{array}$ \\
\hline & Biology & $\begin{array}{l}\text { Pupils describe changes in nature caused by people and } \\
\text { explain their consequences }\end{array}$ \\
\hline Man and Society & Civics & $\begin{array}{l}\text { Pupils explain the connections between global and local } \\
\text { problems; pupils also show examples about the possible } \\
\text { results and solutions to global issues at a local scale. }\end{array}$ \\
\hline
\end{tabular}




\section{Description of the Learning Activity 'New Age Atlantis'}

Introduction of activity. What do we need to know before the realisation of the introductory part of the activity?

$\checkmark$ The first part of the activity deals with a fish autopsy that supposedly comes from the New Age Atlantis.

$\checkmark$ To prepare the basic autopsy tools - pad, incisor (scalpel), gloves, tissues, dishtowels and the object of the autopsy itself - represented by aquarium fish that have been fed small pieces of plastic a week beforehand.

$\checkmark$ To make the activity even more interesting for the pupils, we can prepare a mask and gloves for those that perform the autopsy.

\section{Opening autopsy of a fish, which comes from the 'New Age Atlantis'}

[10 mins.]. This part of the activity serves as an introduction for pupils on the given issue. Without any explanation beforehand, we drop the pupils right into the process. We ask questions such as 'Why do they think we have a fish here?', 'Where does the fish come from?' and 'what is the topic we are about to deal with?' The motivational introduction should arouse interest in pupils concerning what will soon follow and raise basic questions.

After the introductory part, we arrive at the autopsy itself. We ask a volunteer to wear protective equipment and begin the autopsy. We supervise the autopsy and provide advice on how best to carry it out. After opening the fish's body, pupils can see small pieces of plastics that were fed to the fish. Other questions will concern the origin of the fish and how the contact with plastics could have been possible (Kössl \& Chábera, 1999; TED Conferences, 2009; National Geographic, 2012; Algalita, 2016; MŠMT, 2017).

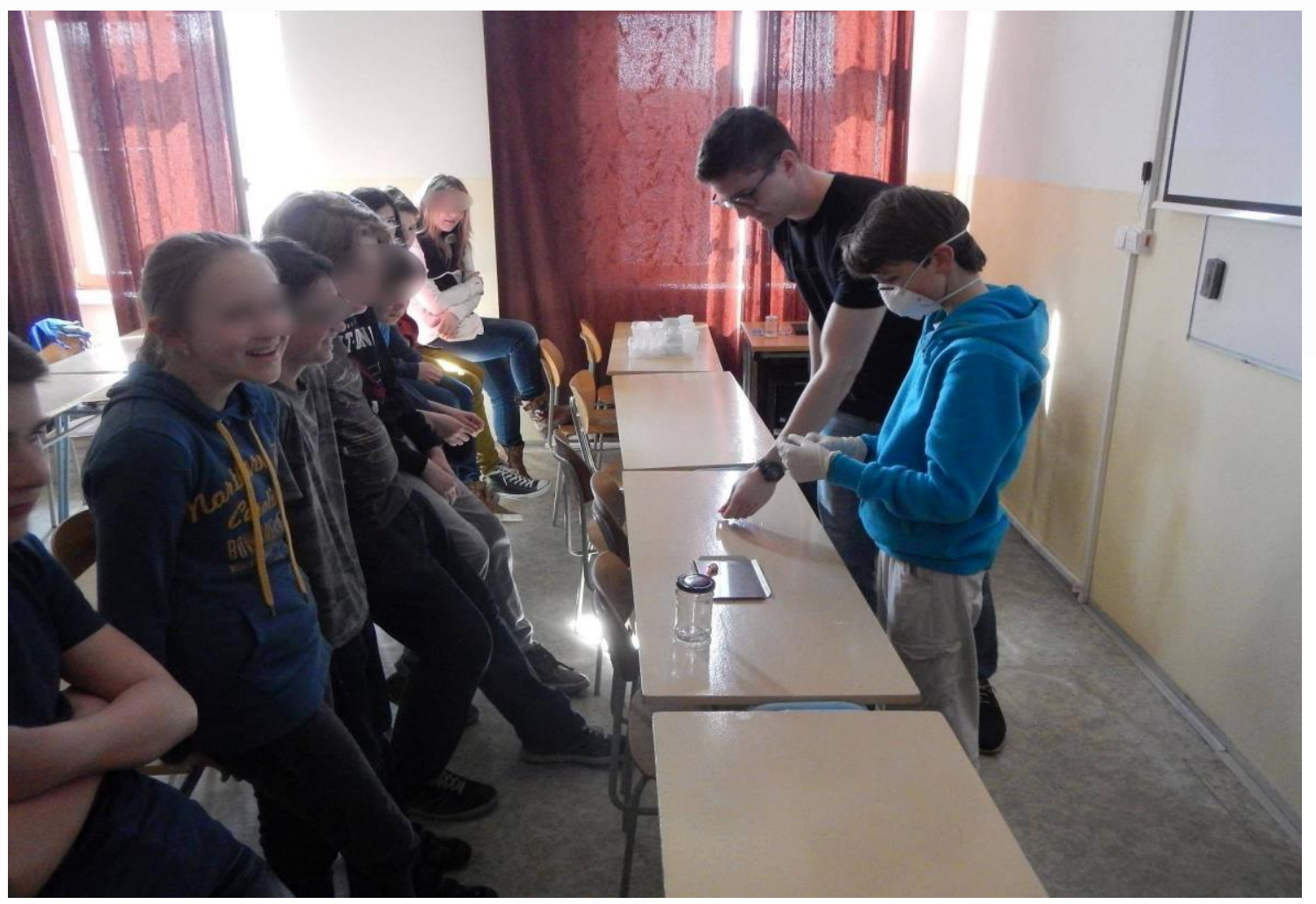

Figure 1. The pupils during the first phase of activity (archive of P. Karvánková) 
Karvánková, P., Popjaková, D. \& Mintálová, T. (2020). Using the 'New Age Atlantis' Case Study...

Questions:

- Where does the subject of the autopsy come from?

- What material does the New Age Atlantis consist of and how could it even come into being?

Discussion part with video [15 mins.]. A short documentary is shown. The documentary is called On the Seas of Plastic (seven minutes) where Charles Moore (explorer from Algalita Marine Research Foundation) talks about the plastic pollution occurring in the oceans (TED Conferences, 2009).

The video is in the English language but it is also possible to turn on the subtitles in Czech. We recommend that the teacher stops the video during the passages with important facts which pupils should record and remember. The teacher should also draw attention to these facts and explain them if needed. Only then, should the teacher continue to play the video. The video itself deals with the topic of plastic waste in seas and oceans. The 'researcher' of the New Age Atlantis, Charles Moore, appears in the video, and focuses on the issue of longterm ocean pollution. The video also contains many statistics and authentic image material.

The 'researcher' describes the waste cycle and answers basic questions such as 'How does the waste get to these places?', 'What does the waste make?' and 'How does the waste move?' The 'researcher' also deals with the process of the formation of waste spots through asking questions such as 'What causes its clustering?' and 'What are the waste disposal options?' At the end of the video, the researcher considers the future and possible changes that human society must consider making.

Questions concerning the video:

- What interested you most from the video?

- The video deals mainly with the pollution in the USA-- do you think that we have similar issues in Europe?

- Have you noticed any possible solutions of the plastic pollution issue?

Main part of activity [20 mins.]. What is needed before implementing the activity? The physical experiments dealing with the sea current issue and water salinity measurement (during which, pupils will have a chance to see which way the water in the world ocean moves naturally).

Water streams in oceans. Equipment required to carry out the experiment:

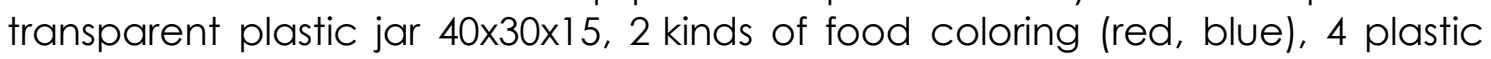
cups, ceramic jug, water, ice cubes, and kettle.

Course of the experiment. Stand 4 plastic cups on the table, upside down. Place the transparent plastic jar on the cups and fill it to $3 / 4$ with room temperature water. Take a new plastic cup and fill it half with water, add 3 ice cubes and blue food coloring. Stir thoroughly. Put the red food coloring into the ceramic jug and fill it with boiling water. Stir thoroughly. Pour half of the mixture from the plastic cup into one of the corners of the plastic jar. Into the second corner, pour half of the mixture from the ceramic jug. Then stand the ceramic jug under the spot of the plastic jar where half of the mixture was poured. The jug works as a source of heat during the following phases of the experiment. 
Run of the experiment. Hot (red) water rises towards the surface and then it makes its way to the second corner of the jar, where it heats up the cold (blue) water. Both colors (waters) mix here and sink, and then they make their way towards the heating source. The model of general circulation of ocean water is made this way.

Lamination of the ocean water according to their various characteristics.

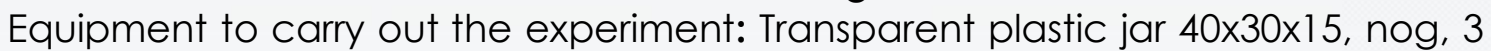
kinds of food coloring (red, blue, yellow), salt, teaspoon, plastic cups, ceramic jug, water, kettle.

Course of the experiment. Tilt the transparent plastic jar, pad it with an item to act as a chock on one side and fill it with room temperature water so the water reaches one $\mathrm{cm}$ below the edge of the jar while tilted. Now, prepare three different types of water for the experiment. Put the yellow food coloring into one of the plastic cups, add salt and pour in room temperature water to halfway. Stir thoroughly. Add the blue food coloring into the second cup and fill with room temperature water. Stir thoroughly. Add the red food coloring into the ceramic jug and fill halfway with boiling water. Stir thoroughly. After that, start pouring the mixtures into the transparent plastic jar. At first, pour in the yellow mixture slowly from the raised side. Watch the movement of the mixture in the jar. After it settles down, pour in the content of the second cup with the blue food coloring. Again, watch the movement of the mixture. Lastly, pour in the red mixture from the ceramic jug and watch the process again.

Run of the experiment. The yellow mixture sinks to the bottom of the jar. The blue mixture laminates on the right and the yellow one into the transparent jar. The red water laminates on the surface and afterwards during the cooling, it sinks down to the bottom. Pupils can try to comment on the run of the experiment and stating a hypothesis about why it happens this way.

Conclusion of activity [20 mins.]. At the end of the experiments, it is good to have a wrap-up discussion supported by the questions below. The intention of the discussion is to incite the development of pupil responsibility for their surroundings, and to encourage a modification of pupil behavior towards the values of sustainable and ecological development as a way of life. At the same time, the discussion focuses on the development of critical thinking skills and exploration of the issue at a global level. During the discussion, pupils can work with information gained during the presentation as a whole, but one's own experience and opinions are also welcome. 


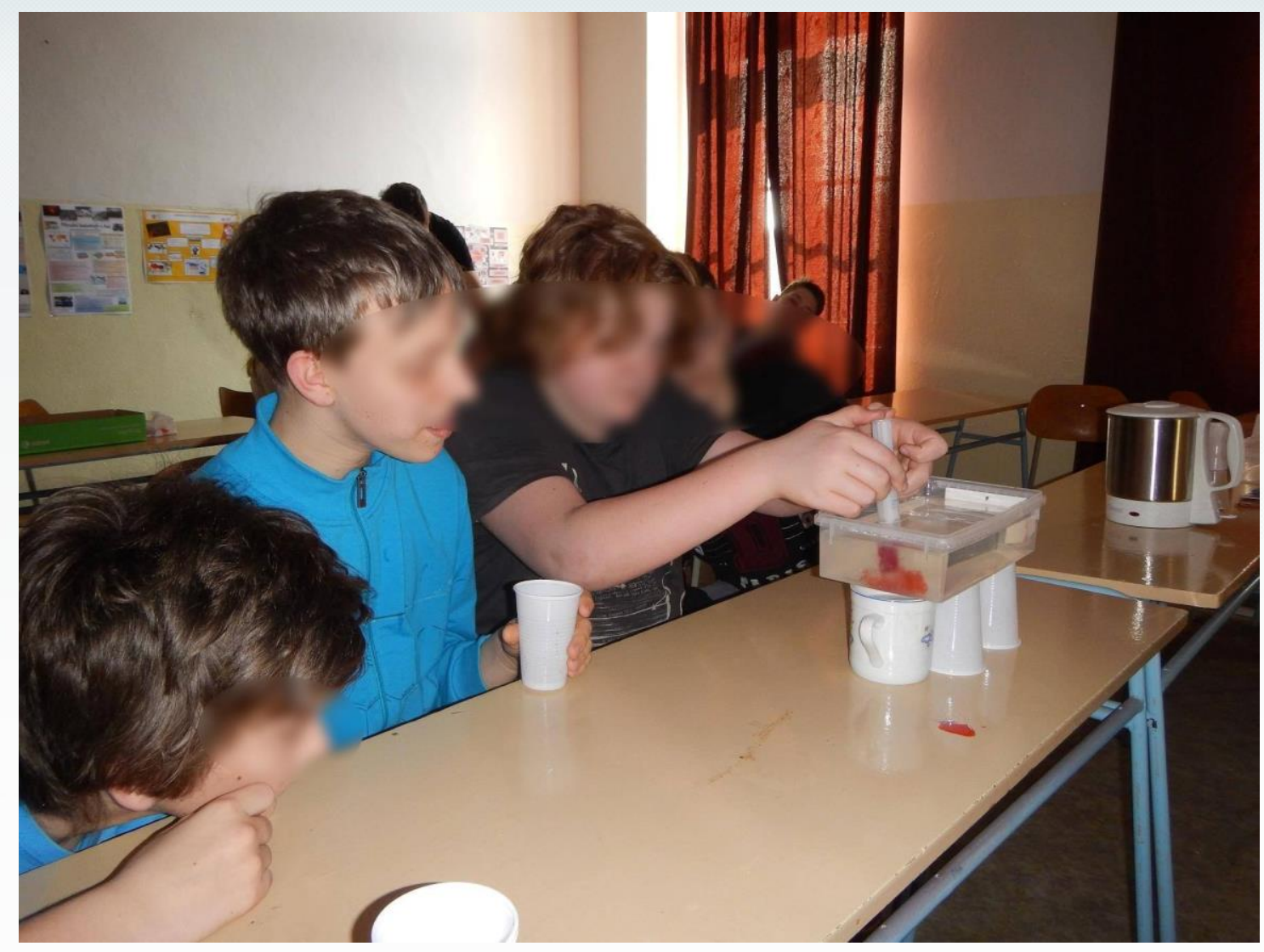

Figure 2. The pupils during the third phase of activity (archive P. Karvánková)

Questions:

- Do you think that the inland countries (e.g. Czechia) contribute to the sea pollution?

- How can the pollution affect us? Is it our problem?

- Can you think about how we can prevent sea pollution and how to act while solving the issue?

- Which ways does waste get into the ocean?

\section{Results and Conclusion}

The pupils, who were aged between 12 - 15 years old and attended the participating lower-secondary schools of Czechia, perceive global pollution issues very sensitively. During the brainstorming session at the beginning of the 'New Age Atlantis' activity, they reacted animatedly to the questions about global environmental disasters and ocean pollution. At the end of the activity, pupils started to demonstrate an appreciation for their own concrete experiences gained from the practical exercises. The learning outcomes of the case study were assessed through observation of 25 groups of pupils as they completed the "New Age Atlantis" case study. Learning outcomes were also assessed from interviews and small surveys responses. The surveys were given to pupils at the end of activity and questions were based on the questionnaire forms conducted by the Master's students. The results of the observation were 
compared and contrasted with initial suppositions, the author's hypothesis of the case study, and also with the conclusions drawn from other studies and authors.

The results from use of the case study confirms that not only do pupils manage to collaborate and communicate with their peers and teachers, they also learn to critically accept the opinions of others whilst at the same time be able to defend their own opinions. All of the pupils were able to understand and recognize a GE problem. Activities such as those in the 'New Age Atlantis' case study enable pupils to develop critical thinking processes about the issue at a global scale. The activities also enable pupils to understand the natural processes of a particular example and to raise awareness about environmental issues. An awareness about individual responsibility for their surroundings will enable pupils to adapt their behavior towards the values of sustainable development and an eco-friendly way of living as a preferred way of life.

Global Education (GE) should develop in students the basic skills of communication, civic responsibility, social and personal competencies, critical thinking, the ability to cooperate, and an understanding about how to take action towards particular issues. The ambition of GE is not only to gain concrete knowledge and information about the given topic as a whole, but to also focus mainly on the approaches and values of the pupils, and the processes of such development. The school classroom must therefore provide a safe place for the sharing of knowledge, experiences, opinions, and the enactment of pupils' creative approaches towards learning about GE issues.

Teachers can support the pupils' effort by asking open-ended questions, or by scaffolding questions to support creative thinking, or by providing sufficient space for students to think, activate their knowledge and engage with respectful listening. In so doing, teachers are supporting the participation of all pupils, and applying multiple strategies so that pupils with different preconditions and learning styles can participate in the lessons. Teachers must check that all pupils feel safe. Teacher mush also create opportunities for students to share not only their knowledge and experience but also their doubts and fears. It is important for the subject matter itself to be suitable for pupils of different ages so they can develop their understanding about GE issues and ask questions of interest to them. On the other side, teachers stand before a difficult task in attempting to tear down the pupils' stereotypes and provide an experience that will lead the students towards developing a more complex and unprejudiced view of the world.

Global Education (GE) lessons focused on the global issues affecting humanity must be well thought out, because hopelessness or fear should not be aroused in the pupils. On the contrary, GE lessons should mention examples about successful solutions related to these issues, for example from the contribution of effort from international organizations or state powers and also through individual action. Despite many GE topics being controversial and arousing a sense of dread in pupils, it is impossible not to be concerned with these topics in school education. Pupils come across issues of conflicts, migration, or the spread of illnesses and hunger every day in mass media, the press, or in their own personal lives. Therefore, it is important for pupils to better understand and know that there are possibilities to help ease or solve such issues, possibly thanks to their own work and activity as individual citizens of the world. 
Karvánková, P., Popjaková, D. \& Mintálová, T. (2020). Using the 'New Age Atlantis' Case Study...

Pupils search for common elements of our lives through topics of GE, and that brings them closer to understanding more about the developing world. Empathy and solidarity often spark illusions that either we must save the world, or, on the contrary, that our contribution is useless. Everyone can contribute to improvement at an individual level. It is important to want to help, and at the same time, to know how to take the right steps towards it - the steps that emerge from a critical evaluation of diverse information about the world. It is important to take the 'right steps at the right time and at the right place'. For these reasons, GE should not be just a school subject; it should holistically penetrate educational programs and represent a whole-school approach.

\section{Acknowledgement}

This work was supported by the research grant KEGA 015UMB-4/2018: Geography Interactive E-books for Lower Secondary Schools and the research grant GAJU 14/2019/S: Integrated teaching in the preparation of elementary school teachers.

\section{References}

Algalita (2016). Marine Research and Education: Inspiring Solutions to Plastic Pollution. Retrieved from http://www.cee.org/tep-lab-bench/pdf/2016.KA.RT. Talk.pdf

Anderson, L. F. (1968). An examination of the structure and objectives of international education. Social education, 32 (7), 639-47.

Applis, S. (2014). Global Learning in a Geography Course Using the Mystery Method as an Approach to Complex Issues. Review of International Geographical Education Online (RIGEO), (4) 1, 58-70.

Baker, T. R., Battersby, S., Bednarz, S. W., Bodzin, A. M., Kolvoord, B., Moore, D., Sinton, D., \& Uttal, D. (2015). A research agenda for geospatial technologies and learning. Journal of Geography, 114 (3), 118-130.

Belgeon, C., \& Crombie, B. (2013). Globální dimenze ve výuce. Příručka pro vzdělávání učitelů. Manchester: Development Education Project.

Bourn, D. (2008). Education for Sustainable Development and Global Citizenship. Theory and Research in Education, 6(2), 193-206. doi: 10.1177/1477878508091112

Bullivant, A. (2014). Examples of Good Practice in Development Education from UK. Teachers Agents of Change. Liverpool: Liverpool Hope University.

Cabezudo, A., Christidis, C., Carvalho de Silva, M., Demetriodou-Saltet, V., Halbartschlager, F., \& Mihai, G.-P., (2008). Global education guidelines. A handbook for educators to understand and implement global education. Lisbon: North-South Centre of the Council of Europe. Retrieved from https://rm.coe.int/168070eb85. Accessed 5. Apr 2020.

Dudková, L., Tillová, K., Halbartschlager, F., Náprstek, M., Pospiechová, R., Vacková, H., \& Vymětal, J. (2012). Na stopě začleňování globálních témat do výuky. Olomouc: Agentura rozvojové a humanitární pomoci Olomouckého kraje, o.p.s.

Hicks, D. (2003). Thirty years of global education: a reminder of key principles and precedents. Educational Review, 55(3), 265-275. doi: 10.1080/0013191032000118929

\|lérová, J. (2015). Globální rozvojové vzdělávání. Proč je nezbytné pro českou společnost a udržitelný rozvoj. Praha: FoRS. 
Karvánková, P., Popjaková, D., Vančura, M., \& Mládek, J., (Eds.). (2017). Current Topics in Czech and Central European Geography Education. Heidelberg: Springer.

Katedra geografie (2019). Zeměpisný badatelský klub. Retrieved from http://www.pf.jcu.cz/structure/departments/kge/zemr-pisn-z-badatelsk-zklub.html

Kössl, R., \& Chábera, S. (1999). Základy fyzické geografie: přehled hydrogeografie. České Budějovice: Jihočeská univerzita.

Morgan, A. (2006). Developing geographical wisdom: postformal thinking about, and relating to the world. International Research in Geographical and Environmental Education, 15(4), 336-352.

MŠMT ČR - Ministry of Education, Youth and Sports of the Czech Republic (2017). Framework educational program for basic education. Retrieved from http://www.nuv.cz/file/195

MZV ČR - Ministry of Foreign Affaires of the Czech Republic (2011-15). National strategy for global development education. Retrieved from https://gene.eu/wpcontent/uploads/Gene_NationalStrategy-CzechGDE201 1EN.pdf

Nádvorník, O., \& Volfová A. (2004). Společný svět. Příručka globálního rozvojového vzdělávání. Praha: Člověk v tísni společnost.

National Geographic (2012). Sedmý kontinent je z odpadků. Má čtyřikrát větší rozlohu než Německo. Retrieved from: https://www.nationalgeographic.cz/clanky/sedmy-kontinent-je-z-odpadku-ma-ctyrikrat-vetsi-rozlohunez-nemecko-20180712.html? photo=1

O'Loughlin, E., \& Wegimont, L. (2008). Quality in global education: An overview of evaluation policy and practice. Amsterdam: Global Education Network Europe GENE.

Pána, L., \& Pospísiilová, K. (2012). Globální souvislosti, problémy a výchova. České Budějovice: Vysoká škola evropských a regionálních studií.

Pike, G. (1997). The Meaning of Global Education: From Proponents' Visions to Practitioners' Perceptions. University of York, Department of Educational Studies. Thesis.

Pike, G., \& Selby, D. (1988). Global teacher, global learner. London Hodder \& Stoughton.

PINcz - People in Need Czechia (2019). Varianty. Global development education. Retrieved from https://www.clovekvtisni.cz/en/global-development-education$5959 \mathrm{gp} /$

Tarozzi, M., \& Inguaggiato, C. (2018). Implementing global citizenship education in EU primary schools: The role of government ministries. International Journal of Development Education and Global Learning, 10(1), 21-38.

TED Conferences (2009). Charles Moore: On the Seas of Plastic. Retrieved from: http://www.ted.com/talks/capt_charles_moore_on_the_seas_of_plastic/

Vaňková-Klímová, Z., \& Gajdíková, I. (2013). Humanitární pomoc a rozvojová spolupráce $\checkmark$ hodinách zeměpisu. Praha: Charita Česká republika.

\section{Biographical Statements}

Petra KARVÁNKOVÁ has been working as an Assistant Professor since 2007 and as an external lecturer at the geography seminar at the secondary school since 2012. She is focused mainly on the teaching of geography and physical geography. She has been participated 14 grant projects until now. 
Karvánková, P., Popjaková, D. \& Mintálová, T. (2020). Using the 'New Age Atlantis' Case Study...

Dagmar POPJAKOVÁ works as the Associate Professor in Matej Bel University, Department of Geography and Geology. Her research is focused on the geography teaching, the study of population and internal migration as well as on the industrial structures of regions. Tatiana MINTÁLOVÁ worked at the Departments of Geography in Slovakia (Prešov, Banská Bystrica) and Czech Republic (Olomouc). Her research focuses on the landscape, peripheral regions and, more recently, on the methods of geography teaching as well. 